\title{
Working
}

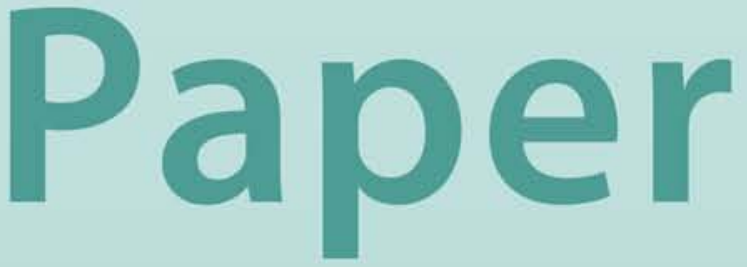


Regional Financial Conglomerates:

A Case for Improved Supervision

Julia Majaha-Jartby and Thordur Olafsson 


\title{
IMF Working Paper
}

Monetary and Financial Systems Department

\section{Regional Financial Conglomerates: A Case for Improved Supervision}

\author{
Prepared by Julia Majaha-Jartby and Thordur Olafsson ${ }^{1}$ \\ Authorized for distribution by David Marston
}

June 2005

\begin{abstract}
This Working Paper should not be reported as representing the views of the IMF. The views expressed in this Working Paper are those of the author(s) and do not necessarily represent those of the IMF or IMF policy. Working Papers describe research in progress by the author(s) and are published to elicit comments and to further debate.

The paper's central theme is that where a financial crisis emerges, regional supervisors should have systems in place to effectively respond to their country-specific crises and-in the case of foreign operations and financial conglomerates - to collaborate comprehensively with other supervisory agencies and respective ministries to avert a regional crisis or address the immediate crisis at hand. For financial institutions to expand across borders without undermining regional and global financial stability, supervisory agencies must develop the capacity to collaboratively and collectively handle crises.
\end{abstract}

JEL Classification Numbers: G21, G28

Keywords: Supervision, large and complex financial institutions, regional cross-border conglomerates, crisis management

Author(s) E-Mail Address: imajahajartby@imf.org; tolafsson@imf.org

\footnotetext{
${ }^{1}$ Julia Majaha-Jartby and Thordur Olafsson are with the IMF's Monetary and Financial Systems Department. The authors are grateful to Steen Byskov for his research assistance, Socorro Heysen and the Monetary and Financial Systems Department seminar participants for valuable comments and suggestions, and Natalie Baumer for editing the draft. All errors are the authors' sole responsibility.
} 


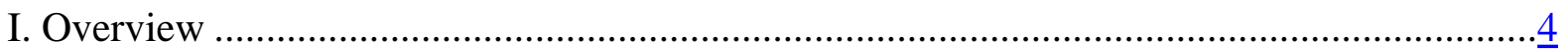

II. Main Risks and Surveillance Work..................................................................................

A. Main Risk Areas in Operation of Large and Complex Financial Institutions ........... $\underline{6}$

B. Lessons from IMF Surveillance Work ....................................................................

III. Recent Developments in Nordic Region.........................................................................

A. Cooperation Among Nordic Countries ..................................................................

B. Overview of Financial Markets and Supervision....................................................

C. Nordea Group ................................................................................................ 14

D. Supervision of Nordea Group PLC ........................................................................

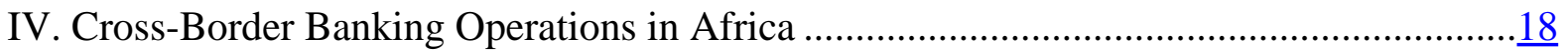

A. Standard Bank Group ......................................................................................21

B. Supervision of Financial Sector in South Africa and Collaboration on Cross-

Border Surveillance .............................................................................................23

V. Regional and Foreign Bank Ownership in Latin America...................................................24

A. Supervision of Financial Sector in Latin America..................................................26

VI. Case for Signing Memoranda of Understanding ……......................................................

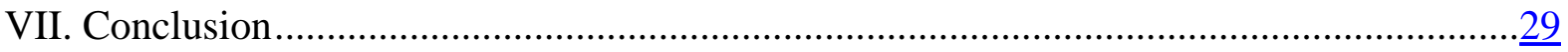

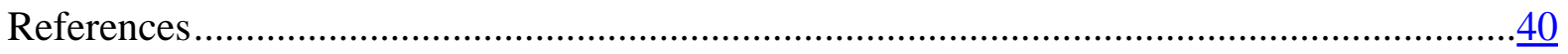

Tables

1. Macro and Financial Sector Indicators in Nordic Countries …………...............................10

2. Brief History of Nordea Group ..............................................................................

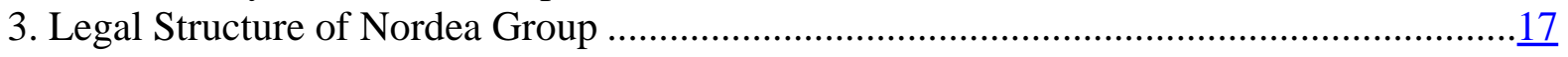

4. Selected Sub-Saharan African Countries: Market Shares of Standard Bank Group’s

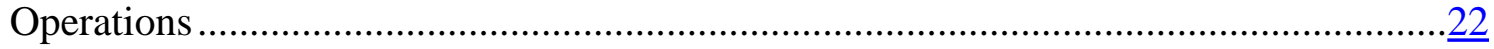

Figures

1. Selected Sub-Saharan African Countries Ratio of Private Sector Credit to GDP ……….....20

2. South Africa: Ratio of Premium to Total Assets .............................................................

3. Foreign Control in Latin American Banking System .........................................................25

Boxes

1. European Union (European Central Bank and National Banking Supervisory Authorities) and Nordic Central Banks’ Memoranda of Understanding ..............................................12

2. Highlights of Key Guidelines in the Memorandum of Understanding Between Nordic Financial Supervisory Authorities ..................................................................................13 
3. Highlights of Main Content of Memorandum of Understanding Regarding Cooperation in

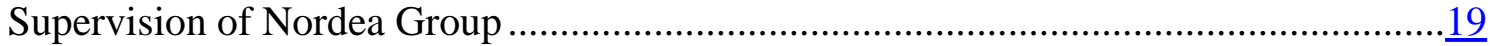
4. Supervisory Collaboration and Cooperation in Eastern and Southern Africa .....................24

Appendices

I. Memorandum of Understanding Among Nordic Central Banks.......................................31

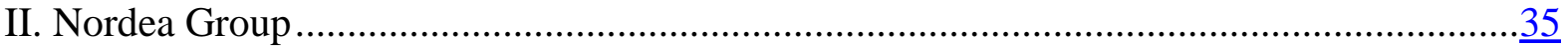




\section{OVERVIEW}

The relevance of large and complex financial institutions (LCFIs) or conglomerates and regional cross-border financial conglomerates ${ }^{2}$ to the financial stability of countries is becoming an important consideration in assessing the management of financial crises. Following the collapse of the Bank of Credit and Commerce International (BCCI) in 1991 and - although it was of lesser significance - that of Meridien International Bank Group in 1995, supervisors have been at work on developing more effective supervision for early detection of financial sector vulnerabilities.

Supervisory concerns are twofold with respect to regional cross-border establishments. First, the goals of supervision aim at ensuring that a system of supervision discourages regulatory arbitrage. For foreign bank operations, this means that arrangements for licensing banking organizations and the scope of activities governed by licenses are clearly defined (by the host supervisor) and that the parent supervisor (home supervisor) provides adequate oversight of not only the bank's overseas branches but also its joint ventures and subsidiaries. Secondregarding modalities for supervision - it is understood that systems are in place to facilitate collaboration among related supervisors and mechanisms for responding to emerging problems in individual banks and systemic crises. This is especially challenging where crossborder operations are carried out by LCFIs.

The Principles for the Supervision of Banks' Foreign Establishments, issued by the Basel Committee on Banking Supervision (BCBS) in May 1983 and generally known as the "Concordat," and later supplements identify the roles and responsibilities of home- and hostcountry supervisors in the licensing and ongoing supervision of a bank. The Concordat also establishes the principles for supervisory cooperation and sharing of information between home and host supervisors. Minimum Standards for the Supervision of International Banking Groups and their Cross-Border Establishments - a paper setting out four minimum standards governing the supervision of cross-border settings-was issued by the BCBS in July 1992, and The Supervision of Cross-Border Banking - a report prepared by the BCBS in collaboration with the Offshore Group of Banking Supervisors-was issued in October 1996. The paper contains 29 recommendations aimed at reducing impediments to the effective supervision of banks and securities operations.

Although there continues to be an enhancement of guidelines for the supervision of the key financial sectors in most economies - in particular, banking, securities firms, and insurance companies — cross-sector supervision has not received the important attention it deserves. The results of most IMF-World Bank Financial Sector Assessment Programs (FSAPs) have

\footnotetext{
${ }^{2}$ LCFIs are defined here as cross-border financial institutions, which are also cross-sectoral, engaged in at least two of the following activities: banking, insurance, and securities transactions with the potential to threaten regional or global financial stability owing to their size in more than one jurisdiction.
} 
revealed that few countries have systems in place for cross-sector information sharing among supervisory agencies. Few countries have adopted the single financial supervisory authority system. Since conglomeration entails cross-sectoral operations of a combination of banking, insurance, and/or securities, there is a need to address the supervision of LCFIs in a manner that would have sector-specific risks assessed by a relevant authority. ${ }^{3}$

This paper presents a case for countries to develop strategic plans for responding to financial crises linked to regional banking groups or LCFIs, also referred to as financial conglomerates. It examines the supervisory systems of three of the regions that have regional cross-border operations (the Nordic countries, East and Southern Africa, and Latin America) and analyzes their strategies for supervising conglomerates or addressing crises linked to regional cross-border banking groups. ${ }^{4}$

The paper's central theme is that where a financial crisis emerges, regional supervisors should have systems in place to effectively respond to their country-specific crises and-in the case of foreign operations and financial conglomerates-to collaborate comprehensively with other supervisory agencies and respective ministries to avert a regional crisis or address the immediate crisis at hand. For financial institutions to expand across borders without undermining regional and global financial stability, supervisory agencies must develop the capacity to collaboratively and collectively handle crises.

\footnotetext{
${ }^{3}$ In the absence of a single financial supervisory authority, it would be prudent to consider the establishment of cross-border supervisory committees from the respective supervisory agencies to address sector-specific risks in the supervision of LCFIs.

${ }^{4}$ Spanish and U.S. banks have developed considerable activities in Latin America; British banks, in former colonial Africa; Nordic banks, in other Nordic countries and the Baltic states; and, more recently, Western European banks, in Central and Eastern European countries. Among Western European banks, the most significant development is the Austrian banks' expansion to its neighboring countries Croatia, Poland, the Slovak Republic, Slovenia, the Czech Republic, Belarus, and Hungary. South African and Zimbabwean banks, whose activities are discussed in this paper, are gaining operational importance in East and Southern Africa and progressively throughout the continent. Also of note is the dominance of Australian banks in New Zealand.
} 


\section{MAIN RISKS AND SURVEILlANCE WORK}

\section{A. Main Risk Areas in Operation of Large and Complex Financial Institutions ${ }^{5}$}

Risk taking is inherent in providing financial services, and effective risk management is one of the key success factors in the financial sector industry. The complexity of effective risk management on a group basis is evident in financial conglomerates where a broad range of financial services is provided and becomes even more complex in large cross-border financial conglomerates. This is both related to the variety of financial services provided, banking, insurance, and capital market services (securities underwriting and asset management), a variety of other financial services, including participation in payments and settlement systems, and to the cross-border services to other jurisdictions with different legal systems. A tendency for larger international banking institutions to place increased reliance on volatile and other nondeposit sources of funds, increases their exposures to market runs and other liquidity risks. While each business area of the conglomerate is primarily responsible for managing its own risks, it is important that the overall risk management is conducted on a group basis. The main systemic risk areas of LCFIs' activities are related to:

- $\quad$ concentration and cross-sectoral credit, market, liquidity, and technical (insurance) risks arising from interbank and other funding;

- $\quad$ securities, over-the-counter (OTC) derivatives, and other market activities; and

- $\quad$ credit, market and insurance risk-sharing between LCFIs.

Systemic operational and legal risks are mainly:

- $\quad$ large settlement and payment systems exposures;

- $\quad$ management risks increase in response to limits on the ability of senior managers to oversee and control institutions engaged in a wide range of activities across the globe;

- unenforceability of contract arising from differences in home/host insolvency regimes, untested insecure netting arrangements, consumer protection legislation, imposition of exchange controls, and debt moratoria, etc., by foreign governments;

- $\quad$ poor transparency arising from differences in home/host country accounting, financial reporting, and listing;

\footnotetext{
${ }^{5}$ See also Steven A. Seelig and Peter J. Elmer, 2002, "Risks Associated with Mega Financial Institutions,” in “Mega Financial Institutions”: Causes and Consequences, ed. by Benton E. Gup (Westport, Connecticut and London: Quorum Books).
} 
- $\quad$ differences in prudential regulations, monetary policy, market distortions, and transaction arbitrage encouraged by differences in home and host country taxation regimes; ${ }^{6}$ and

- $\quad$ the heavy emphasis on cross-border financial activity raises issues for regulators responsible for supervising these institutions and calls for improved supervision and cooperation among supervisors.

\section{B. Lessons from IMF Surveillance Work}

Recent experiences with financial crises have had important implications for the IMF in assessing country vulnerabilities. In response to this, the IMF and the World Bank have introduced the joint FSAP to help countries detect sources of financial vulnerability and build sound financial sectors. At the earlier stages of the FSAP reviews, the focus has been on assessing country-specific vulnerabilities of the financial system, including issues of systemic importance. However, experience in the usefulness of these assessments points to the need for broader coverage of the FSAP, specifically in the area of the role of cross-border and potentially cross-sector financial conglomerates. Activities of financial groups raise a variety of issues relating to systemic risk in individual countries, inter alia, effective crossborder supervision, home country support, parent bank support, and the cross-border transfer of financial risks.

Useful lessons have been learned from some of the FSAP assessments. For example, the FSAPs prepared for Finland, Sweden, and the Netherlands identified a number of issues related to the supervision of financial conglomerates. The two assessments concluded that conglomerate management complicates supervision and that opportunities for regulatory arbitrage may increase in a conglomerate environment due to a number of factors. In particular, the Finnish FSAP concluded that:

- $\quad$ in a complex structure, bank supervisors may find it difficult to understand the chain of command in the decision-making process and hence, may not appropriately apply "fit and proper" criteria, especially since management and its direction of supervised entities may be influenced by more senior management in unregulated upstream companies;

- $\quad$ the business structure of the conglomerate may be unrelated to the corporate legal structure, making it difficult for the supervisor to obtain an accurate overview of the business;

\footnotetext{
6 "Large Complex Financial Institutions (LCFIs): Issues to be Considered in Financial Sector Assessment Programs,” MAE OP/02/03 (Washington: International Monetary Fund, Monetary and Exchange Affairs Department, Occasional Paper).
} 
- $\quad$ supervisors may have difficulties understanding risk management in a conglomerate where decisions are made in an unsupervised entity; and

- $\quad$ the supervisory structure may not be aligned with the risk management structure of the institution especially when, for example, the head office is overseas. Supervisory communication and information exchange, along with the supervisors' knowledge of corporate control and business structure within the group becomes critical.

At a systemic level, LCFIs have a number of evident characteristics-namely, that they (i) have significant on- and off-balance sheet risk exposures and offer a broad range of products at the domestic and international levels (the foreign portfolio is often larger than the domestic one); (ii) are subject to multiple banking, securities, and in some cases, insurance supervisors in the home country and abroad; and (iii) may carry out a range of nonbanking activities that are not supervised. One issue is the level of consolidation of the data to be used for stress testing. Stress testing on a fully consolidated basis-both across countries and across business lines - may be particularly important in the international financial services companies (IFSCs), where, for example, the transfer of credit risk to insurance companies through credit derivatives is common.

Focusing on domestically owned institutions seems acceptable when there is a clear presumption that the foreign owners of locally incorporated institutions will back up their subsidiaries. However, even when a selective approach is adopted, missions are responsible for addressing the vulnerabilities that other groups of banks may cause to the system, while not carrying out individual stress tests.

Stress testing of nonbanks could identify important vulnerabilities, for instance, in the case of insurance or reinsurance companies that are significant credit risks takers. Insurance companies and other subsidiaries may be stress tested at the level of a conglomerate, which may include banks, but the issue of comprehensive coverage remains for nonbank financial institutions that are not part of a financial group.

\section{RECENT DEVELOPMENTS IN NORDIC REGION}

\section{A. Cooperation Among Nordic Countries}

The level of cooperation characterizing the Nordic countries, ${ }^{7}$ developments today-and which has assumed different forms and has reinforced the common Nordic identity-dates back many centuries. "Scandinavism" is the term used as a designation of the sense of solidarity shared by the people of the Nordic region, for all activities designed to promote cooperation between the Scandinavian people, or to unite them at a political level. In 1952, the Nordic Council was established - a formation of a cooperative body for Nordic parliaments

${ }^{7}$ The Nordic countries are Denmark, Finland, Iceland, Norway, and Sweden. 
composed of representatives from elected members of the national parliaments. The formation of the Council made it possible for Nordic parliamentarians to play a larger role in the process of developing cooperation on legislation. This has gradually led to identical legislation on almost all aspects of the five societies' economic sectors, extensive cooperation in social, cultural, and economic issues. There is a long-standing cooperation between the Nordic central banks and among the Nordic banking supervisory authorities, one that has existed for more than 80 years.

The Nordic countries have enjoyed economic growth and political and economic stability over a long period of time. GDP per capita is among the highest in the world and inflation is low. Each of the Nordic countries are considered small, and one of them (Iceland) is a very small economy. ${ }^{8}$ The total population of the Nordic countries is only 24 million as of end2002 (Table 1).

\section{B. Overview of Financial Markets and Supervision}

The financial markets in the Nordic countries have gone through massive restructuring over the last 20 years. The restructuring is characterized by large mergers of financial institutions and creation of financial conglomerates which offer a broad array of services to the (economy) public.

The financial markets in the Nordic countries consist of a number of local and savings banks - dominated by a few large banks — other credit institutions, insurance companies, and well developed capital markets. The local markets are widely integrated and offer a wide range of financial products, affording customers to do their financial businesses in one place. The financial industry is well equipped with modern information technology, and home banking is nowhere in the world as widely used as in the Nordic countries. The financial intermediation is significant in all of the Nordic countries. The size of the three main financial sectors; banking, insurance, and capital market is covered in Table 1.

Nordic banks have expanded their services to other Nordic countries. Nordic financial institutions are well integrated into countries the world over, being represented in various cities in Europe, also in South-East Asia, and to a lesser extent the United States.

Traditionally, Nordic banks have looked at the Nordic countries as their home market, but in the past few years, the home market has expanded to cover the Baltic countries as well. For example, Swedish banks own the majority of the Estonian and Latvian banking sectors. Under the single license established in the European Union (EU) second banking directive, all credit institutions authorized in an EU country would be able to establish branches or

\footnotetext{
${ }^{8}$ Iceland had GDP of the equivalent of an estimated US\$8.5 billion according to the Central Bank of Iceland Monetary Bulletin 2/2003, available at www.sedlabanki.si.
} 
supply cross-border financial services in all other countries of the EU/EEA ${ }^{9}$ without further authorization. There is one major financial conglomerate which originated in the Nordic countries, which spreads out to the neighboring countries - the Nordea Group.

Table 1. Macro and Financial Sector Indicators in Nordic Countries (In percent end 2002, unless otherwise indicated)

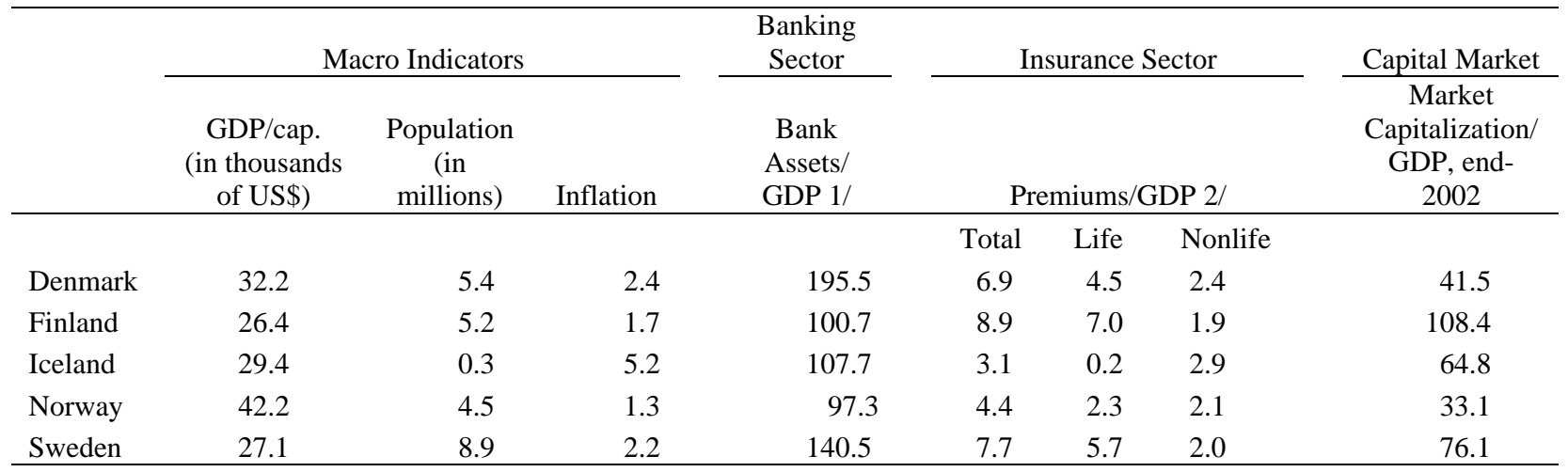

Sources: The Nordic Securities Market; World Insurance in 2001 published by Swiss Re-Insurance Company, International Financial Statistics.

1/ Banks comprise commercial banks and other financial institutions that accept transferable deposits, such as demand deposits. Assets include foreign assets, claims on other private sectors, public sector, and monetary authorities. 2/ Data are for the year 2001.

In June 2003, the governors of the Nordic central banks entered into a crisis management agreement through the signing of a memorandum of understanding $(\mathrm{MoU})^{10}$ outlining the steps that would be taken in case of a financial crisis in banks with cross-border establishments (Box 1 and Appendix I). This dovetailed with the EU's memorandum issued in March 2003, ${ }^{11}$ laying the foundation for cooperation between the banking supervisors and central banks of the EU (see Box 1).

\footnotetext{
${ }^{9}$ Denmark, Finland, and Sweden are members of the EU, while Iceland and Norway are members of the EFTA (European Free Trade Agreement) and have signed special agreements with the EU on the European Economic Area (EEA); making all five countries members of the EEA. Only Finland is a member of the Euro Currency Zone.

${ }^{10}$ Management of a financial crisis in banks with cross-border establishments-MoU between the central banks of Denmark, Finland, Iceland, Norway, and Sweden.

${ }^{11}$ MoU on High-Level Principles of Cooperation between the Banking Supervisors and Central Banks of the EU in Crisis Management Situations. The MoU is confidential.
} 
The Nordic countries' capital markets are rapidly integrating. The Nordic stock exchanges already have the same trading system, same member rules, and have harmonized rules and practices in many other areas. Finland and the Baltic countries have recently joined the integration process that is set to continue in 2004.

In all the Nordic countries, except Finland, the supervisory authority is vested in a single independent and autonomous authority. The Danish Financial Supervisory Authority (Finanstilsynet) was established in 1988; The Financial Supervisory Authority of Iceland (Fjármálaeftirlitið) was established in 1999; The Norwegian Financial Supervisory Authority (Kredittilsynet) was established in1986; and the Swedish Financial Supervisory Authority (Finansinspektionen) was created in 1991. Each of the four countries' supervisory systems for all financial sectors is under one umbrella except in Finland. The Finnish Supervisory Authority (Rahoituskastus) operates in connection with the Bank of Finland but is an independent decision making body. However, the supervision of the insurance market is within the ministry of finance (MoF).

As previously noted, the supervisory authorities in the Nordic countries have a long-standing cooperation which has lasted for more than 80 years. A high level meeting is conducted at least once every year, and more frequent meetings are held between various working groups and ad hoc groups. There has been a program of exchange of employees for a number of years. A formal MoU between the Nordic banking supervisory authorities was first signed in 1989 and was later renewed in 1994 and again in 2000. The memorandum sets out the main principles for the cooperation, and in more detail, the cooperation related to supervisory responsibilities of cross-border establishments. Highlights of the key guidelines in the MoU of 2000 are contained in Box $2 .^{12}$

\footnotetext{
12 The MoU was agreed to by the following entities: The Banking, Insurance, and Securities Commission of Norway, the Swedish Financial Supervisory Authority, The Financial Supervision Authority in Finland, The Insurance Supervision Authority in Finland, The Financial Supervisory Authority in Iceland, and The Financial Supervisory Authority in Denmark regarding cooperation concerning supervision of credit institutions following the implementation of the second banking coordination directive, supervision of insurance undertakings following the implementation of the third nonlife insurance directive and the third life assurance directive, and supervision of investment firms following the implementation of the investment services directive. The MoU is confidential.
} 


\section{Box 1. European Union (European Central Bank and National Banking Supervisory Authorities) and Nordic Central Banks’ Memoranda of Understanding}

The objective of the European Union' MoU, entered into on March 1, 2003, is to provide guidance on steps to enhance cooperation between banking supervisors and central banks on information sharing procedures to ensure two essential points: (i) relevant information flows at the first signs of a potential crisis; and (ii) timely release of information to the relevant authorities as the crisis unfolds. The framework applies in crises with potential cross-border impact affecting individual credit institutions, banking groups or banking components of financial groups, as well as to disturbances in money and financial markets and market infrastructures, including payments infrastructures with potential common implications for member states. Within the context of member countries pursuing their respective policy functions and tasks and ensuring overall stability of the financial system, the MoU provides the following guidelines:

- With respect to crises involving individual credit institutions, the respective home-country supervisors and central banks are responsible for assessing the emergence of a potential crisis, with host-country central banks also assuming crisis management responsibilities as per supervisor arrangements in place.

- $\quad$ Supervisors and central banks, whose policymaking functions may be affected by the crisis, are likely to be involved in the crisis and, thus, they should receive the relevant information.

- $\quad$ For banking groups or banking components of financial groups, which may materially impact more than one country, specific ex ante agreements may be reached among the relevant supervisors and central banks, specifically defining the respective responsibilities and organization of information flows, and, if need be, the mechanisms for coordinating policy actions.

- $\quad$ Guided by an indicative list provided by the MoU, relevant issues include (i) an assessment of potential systemic implications; (ii) full delegation of the information sharing responsibility with foreign supervisors to the central bank; (iii) strict confidentiality of the information exchange; (iv) maintenance of an "information handbook" with a mapping of information sources within the EU for crisis management purposes; and (v) a review of the MoU within three years—or earlier and as warranted —of its effect.

The Nordic central banks state, as their main principles in the MoU entered into in June 2003, the swift and efficient cooperation in dealing with a financial crisis among the affected central banks, and that a nonlegally binding MoU is an appropriate instrument for facilitating cooperation between the central banks without curtailing their flexibility as independent institutions. The MoU is based on the European system of central banks. The agreement provides for crossborder cooperation in two or more Nordic countries and is based on the following guidelines:

- $\quad$ The responsibility for managing a financial crisis rests primarily with the bank' owners and management (extending to banking groups or group of companies), and emergency liquidity will only be provided in exceptional circumstances. The underlying emergency liquidity support is for the bank to be judged solvent. Insolvency or uncertainty about solvency requires the immediate information of the MoF.

- $\quad$ The crisis management group will be responsible for the establishment of a contact group in the event of a crisis. The group should consist of one high-level representative from each of the concerned central banks and an alternate representative.

- The crisis management group shall provide all central banks with rapid access to the same information and to enable the direct discussion and coordination of potential measures. The activation of the crisis management group shall be by the central bank which first identifies the potential crisis and shall continue to be responsible for the coordination of the group's work.

- The crisis management group shall also be responsible for providing background material for an understanding of the systemic importance of the crisis, and for ascertaining the bank's liquidity and solvency position through direct communication with the management of the banking group to enable decision making under established procedures by the respective central banks.

- The crisis management group shall be the main information solicitor within and outside the Nordic central banks and shall, as requested, produce background material for communications with other international bodies. The group shall also be the focal group for information dissemination to the media.

- Communications with a supervisory group, where it has been established, shall be by the crisis management group; but individual central banks shall handle communication with the respective country's supervisory authority and MoF. The group shall only communicate with banking group management and not individual banks in the group.

- $\quad$ Bilateral MoUs require the creation of fact books for Nordic cross-central bank information sharing. 


\section{Box 2. Highlights of Key Guidelines in Memorandum of Understanding Between Nordic Financial Supervisory Authorities}

The MoU based on the EU directive provides for specific MoUs to be signed with respect to the supervision of large bank branches or financial conglomerates. ${ }^{1}$ The following are the main headings of the MoU:

\section{General provisions}

This chapter contains general provisions related to confidentiality and definitions related to individual supervisory agencies.

\section{Establishing of branches}

This chapter provides detailed guidelines on the establishment of branches in any of the member countries; information required for registration and cross-border cooperation. Frequent references to the EU directives governing the cross-border establishments within the EU appear, as well as suggestions on how to deal with applications from financial institutions outside the EU/EEA.

\section{Cooperation within the supervisory region}

This chapter deals with home and host country responsibilities, information sharing, and cooperation on certain defined risk areas such as market and liquidity risks. There are also provisions on how to address eventual violation of laws and regulations in the host country and information sharing between the host and home supervisory authorities under such circumstances.

\section{Cooperation on conducting on-site examinations}

Home supervisory authorities are free to conduct on-site supervision according to their own procedures at any time. The host supervisory authority's concurrence is implicitly provided for in the MoU. However, notification by the home supervisory authority of plans to conduct an on-site examination is required. The host authority may participate in the examination. The results of the examination are shared with the host authority, whether or not there was dual examination. Other important cooperation issues are also addressed in the chapter.

\section{Cooperation related to consolidated supervision and cross-border financial services}

This chapter stipulates there must be cooperation on consolidated supervision and in cases where financial institutions own qualified interest in another institution. Cooperation is also required when financial services are provided cross-border without firm establishment in the country where the service is provided.

\section{Cooperation related to establishing of affiliate companies}

According to the provisions in this chapter, close consultation is required between the home and host supervisory authorities in the case of establishing affiliate companies, expansion of cross-border activities, and cross-sectoral establishments. The respective authorities shall provide information to the extent possible according to national legislation.

\section{How to deal with crises situations}

The MoU requires that the supervisory agencies promptly report any indications-which could lead to insolvency of the parent company, the conglomerate or its affiliates — of an imminent threat of a crisis situation of any of the supervised objectives or their affiliates.

\section{Technical issues}

This chapter includes a number of technical issues and emphasizes the need for regular meetings between the supervisory authorities.

1/ A separate MoU between the supervisory agencies in Denmark, Finland, Norway, and Sweden has been signed to guide the supervision of the Nordea Group. 


\section{Nordea Group}

The Nordea Group comprises four Nordic banks: Merita Bank, Nordbanken, Unibank, and Christiania Bank of Kreditkasse, from Finland, Sweden, Denmark, and Norway, respectively. Table 2 outlines the brief history of the Nordea Group and events leading up to its formation. Detailed information on events prior to the formation of the group and latest changes of the group are described in Appendix II. Since December 2001, all operations have been conducted under the name of Nordea (Nordic Ideas).

The Nordea Group is the largest financial services group ${ }^{13}$ in the region with approximately EUR 262 billion in total assets:

- $\quad$ A world-leading internet banking and e-commerce operation with 3.7 million customers, and is characterized by the following;

- $\quad$ significant positions in the Nordic banking markets: 40 percent in Finland, 25 percent in Denmark, 20 percent in Sweden, and 15 percent in Norway;

- $\quad$ significant share of assets in the Nordic insurance markets. Life insurance: Finland 35 percent, Denmark 10 percent, Norway 9 percent, and Sweden 6 percent;

- the largest customer base of any financial services group in the region, including 9.6 million personal customers, 0.9 million corporate customers, and 1,000 large corporate customers;

- $\quad$ A leading asset manager in the Nordic financial market with EUR 113 billion (including private banking) under management; and

- $\quad$ The most comprehensive distribution network in the region including 1,224 bank branch offices, leading telephone banking, and Internet services.

Nordea is the leading financial services group in the Nordic and Baltic Sea regions and operates through three business areas: retail banking, corporate and institutional banking, and asset management \& life. As indicated earlier in Table 1, the Nordea is the largest Nordic bank, ranking $49^{\text {th }}$ in the top 1,000 banks assessed by The Banker magazine (July 2003).

Besides being represented in the Nordic Baltic region and throughout Europe, Nordea is also represented in China, Iran, Singapore, Brazil, and the United States.

${ }^{13}$ Nordea's website www.nordea.com. 
Table 2. Brief History of Nordea Group ${ }^{1}$

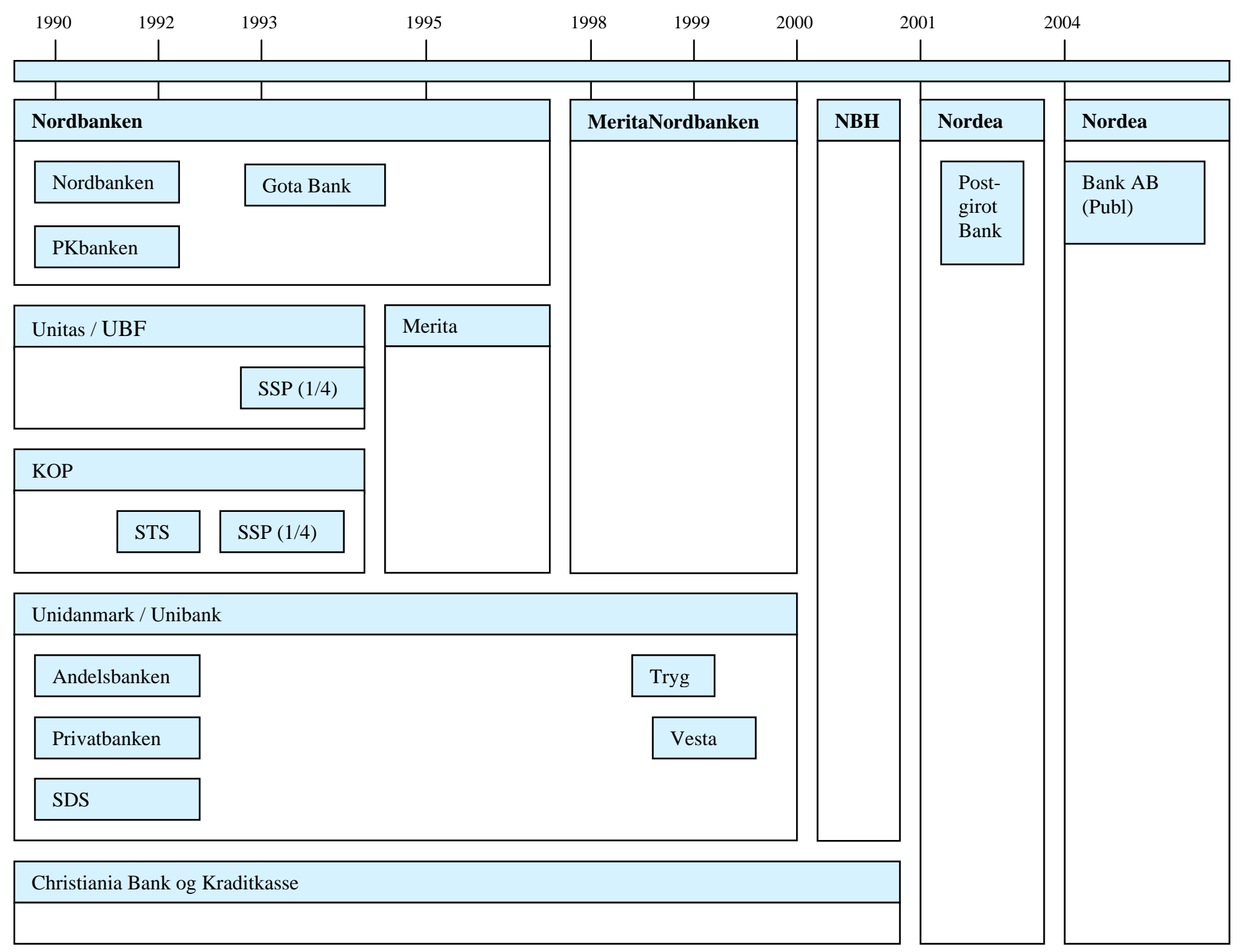

1/ For detailed explanations on the development of the Nordea Group, see Appendix II.

Nordea shares are listed on Stockholm, Helsinki, and Copenhagen stock exchanges. Nordea Bank PLC in Sweden, the parent company of the Nordea Group, is a holding company and subject to Swedish law and supervision by the Swedish Financial Supervisory Authority. Each of the group's banks, their branches, and subsidiaries are established according to the legislation in force in the respective countries and are also subject to home-country supervision (Table 3) on the present legal structure of the Group. 
The life insurance is operated through two holding companies, Nordea Life Holding A/S registered in Denmark and Nordea Life Finland registered in Finland, both of which own and operate life insurance companies within the holding company structure.

The composition of the group is constantly subject to change as highlighted in Appendix II. In June 2003, the Board of Directors of Nordea PLC announced the decision to reduce the complexity in the group's legal structure (see Table 3) by forming one European company"Societas Europeae," (SE) based on an European statute coming into force in late 2004. In a press release, ${ }^{14}$ the Board argued that "the current legal structure which comprises four national banking groups has proved to be complex from an operational point of view and thus not supporting the Group's business activities in an optimal manner. The aim is to establish a one-bank structure, with one legal entity conducting business in all local markets through branches.” As of January 1, 2004 the parent company, Nordea AB (publ), merged with Nordea Bank Sweden AB and was granted a bank charter and changed its name to Nordea Bank AB (publ). Nordea Bank Sweden AB (publ) was merged into Nordea Bank AB (publ) on March 1, 2004.

\section{Supervision of Nordea Group PLC}

As discussed earlier, a general MoU was initially signed between the Nordic Banking Supervisory agencies in 1989. The MoU was later revised in 1994, and the latest MoU is since 2000. The general MoU states that notwithstanding its existence, a separate MoU can be signed between the respective authorities on supervision of large branches or financial conglomerates if deemed necessary. For the Nordic Baltic Holding Group (NBH), a separate agreement (MoU) was signed in 2000 between the financial supervisory authorities in Denmark, Finland (both financial sector assessment (FSA) and the insurance supervision), Norway, and Sweden. Iceland has currently no links to the Nordea Group. The latter MoU is regarded as a supplementary agreement to the general MoU between the Nordic supervisory agencies. The MoU was revised in 2001 and is currently in the process of being revised again due to structural changes of the Nordea group. Highlights of the existing MoU is shown in Box 3. The MoU sets out in more detail, specifications of subjects for the exchange of information and procedures for supervision of the entire group-which comprises all the units and companies of the group (including credit institutions, investment firms, insurance undertakings, and branches). In the preamble of the MoU, it is stated that, "the aim (of the $\mathrm{MoU}$ ) is to guarantee effective and comprehensive supervision of the group. The parties shall endeavor to develop close cooperation in order to achieve effective supervision and minimize possibilities of regulatory or supervisory arbitrage. It is important that the parties work to ensure common risk assessment of the group.”

The MoU addresses, in detail, the conduct of supervision. It provides for the creation of a supervisory group comprising representatives of the authorities concerned. The main task of the supervision group is to ensure that an overall risk assessment of the entire group is

\footnotetext{
${ }^{14}$ Press release of June 19, 2003.
} 
undertaken on a regular basis. The responsibilities are set out in more detail in the MoU under the headings: responsibilities, supervision plan, exchange of information, material events (immediate notification of any material events related to the group), and random provisions of the MoU (see Box 3 for more details). The supervisory authority responsible for consolidated supervision chairs the group. The group is expected to meet regularly and at least once a quarter. Subgroups of the supervisory group may be established to address special issues.

Table 3. Legal Structure of Nordea Group

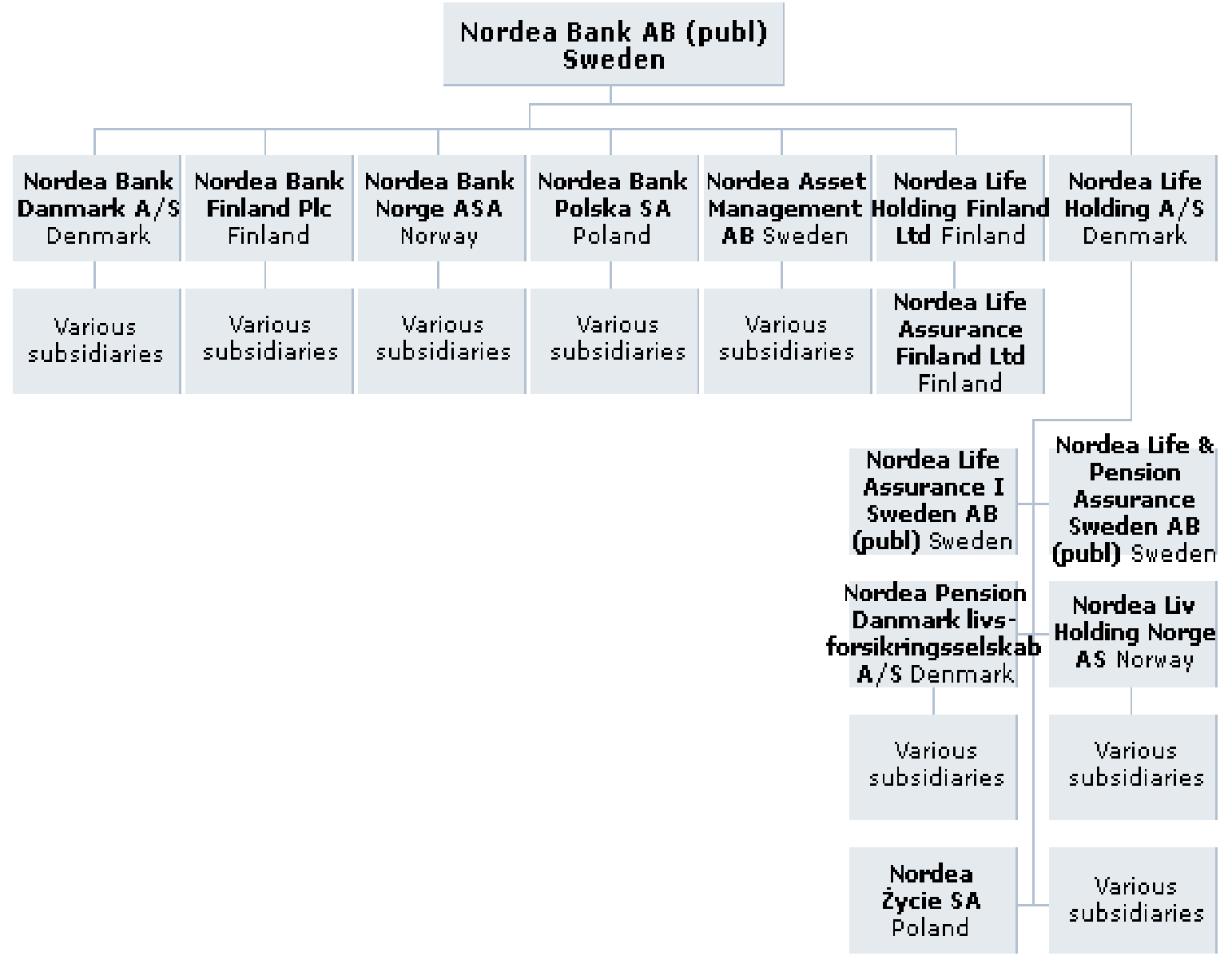

Source: Nordea Group website.

Since the inception of the supervisory group in 2000, the chairmanship has been in the hands of the Swedish Financial Supervisory Authority which also acts as the secretary for the group. The Swedish FSA is also responsible for keeping a list of contact persons handling issues related to the Nordea Group by the respective supervisory authority; and it is also 
charged with the responsibility to update the organizational chart representing the companies in the group. The group meets frequently or at least four to six times a year. The FSA contributes with one person within each of the core risk areas that is, credit, market, liquidity, and operational risks. The same applies to areas such as capital adequacy, insurance IT, accounting, macroeconomic surveillance, legal matters, and anti-money laundering/combating the financing of terrorism. A representative from the Swedish FSA acts as a coordinator for each risk area. The main risk groups meet two to six times a year.

The supervisory authorities shall immediately notify the other parties of any material events or threats affecting the group-in any way they become aware of — such as imminent crises.

The supervisory group shall draw up a contingency plan for dealing with any major problems that may occur in the NBH group. The plan shall also include provisions concerning necessary contacts with the ministries of finance and central banks of the countries concerned. The supervisory authority (authorities) of each individual country shall maintain contacts with their national MoF and national central bank. The formation of the supervisory group to administrate the overall supervision of the NBH has proved to be very useful. The group keeps close contacts with the national supervisory authorities, and they, in turn, have established close cooperation with the respective ministries of finance and central banks. A contingency plan for the group has been drawn up and rehearsed with the participation of representatives from the supervisory authorities and central banks in the respective Nordic countries. The five Nordic central banks have, as mentioned earlier, signed a separate MoU which contains main principles for the swift and efficient cooperation in dealing with a financial crisis among the affected central banks. The agreement provides for cross-border cooperation in two or more Nordic countries and is based on the guidelines set forth in the MoU. The provisions of the MoUs have been tested at a special meeting between representatives from the Nordic central banks and the national financial supervisory agencies. It is envisaged that further rehearsals will be conducted on a regular bases.

The cooperation between the Nordic financial supervisory agencies and financial supervisory agencies in several countries - including those countries where Nordea has representationis concluded on a bilateral basis in the form of formal MoUs. The NBH supervisory group keeps contacts with the other national financial supervisory authorities with respect to supervision of institutions within the NBH according to the NBH MoU.

\section{Cross-Border Banking Operations in Africa}

In Africa, recent economic developments have been encouraging in sub-Saharan Africa (SSA). The driving factors behind these developments include progress in improving macroeconomic policies and supporting institutions as well as in resolving regional conflicts. However, fragile economic fundamentals, excessive concentration of exposures, and weak governance and institutional development have undermined the soundness of financial systems in the major countries. Banking systems require strengthening, as they are often 


\section{Box 3. Highlights of Main Content of Memorandum of Understanding Regarding Cooperation in Supervision of Nordea Group}

The MoU is between Kredittilsynet (the Banking, Insurance, and Securities Commission) in Norway and the following institutions: Finansinspektionen (the Financial Supervisory Authority) in Sweden; Rahoitustarkatus (the Financial Supervision Authority) in Finland; Vakuutusvalvontavrastu (the Insurance Supervision Authority) in Finland; and Finanstilsynet (the Financial Supervisory Authority) in Denmark regarding cooperation in the supervision of the Nordea Group.

The MoU contains the definition of the Nordea Group and subgroups, that is, holding companies and their subsidiaries. The responsibilities of each of the supervisory agencies with respect to supervising the NBH and the various holding companies and subsidiaries are clearly spelled out in the MoU.

The most detailed content of the MoU is under the heading "Conduct of Supervision.” This provides the following:

- $\quad$ A supervision group is established, comprising members from each supervisory authority. The group shall convene regularly and at least quarterly. The group shall ensure that an overall risk assessment of the entire group is undertaken on a regular basis. The establishment of the group does not override the authority of the national supervisory authorities.

- $\quad$ The main responsibility of the supervision group is to coordinate the supervisory activities of the various national supervisory authorities. The group's main tasks will be to do the following: (a) draw up a joint supervisory plan; (b) ensure appropriate exchange of information between the supervisory authorities; (c) conduct joint examinations; (d) ensure proper coordination and notifications of inspections carried out by individual national supervisory authorities in order to avoid, as far as possible, unnecessary duplication of work for the authorities and the NBH; and (e) meet with representatives of the Nordea Group. The group will also be responsible for the maintenance of contacts with foreign supervisory agencies that fall outside the scope of the main MoU (i.e., between the supervisory authorities in all the Nordic countries) concerning matters reviewed by the group.

- $\quad$ An annual supervision plan shall be drawn up containing scheduled supervisory measures on a group level, as well as on a company level. In addition to a yearly plan, another two-year plan shall be outlined. The plan shall be ready in September/October and reviewed at least once a year by the heads of the national supervisory agencies. The supervision plan shall include (a) a consolidated risk assessment of the NBH; and (b) an inspection plan worked out jointly by respective authorities listing the planned on-site examinations conducted both on a group and institutional level. The plan contains a list of main risk areas to which special attention must be paid. There are special provisions in the MoU on the responsibilities of each national supervisory authority and the form and frequency of exchange of information between the authorities on a regular basis and during supervisory actions. It is also stated that wherever possible group-level inspections shall be carried out jointly by the supervisory authorities concerned.

- $\quad$ Each supervisory agency shall inform the other agencies of any material events affecting the Nordea Group in any way that they become aware of, such as imminent crises. A contingency plan shall be drawn up for the group. The plan shall contain necessary contacts with the ministries of finance and central banks in the respective countries. Each of the agencies shall maintain contacts with the respective national MoF and central bank. Any sanctions or substantial actions planned against any of the institutions in the NBH must be mentioned to the other supervisory authorities. The Swedish FSA acts as a secretariat for the supervisory group.

- $\quad$ The staff of the supervisory agencies are regularly exchanged (among agencies) for information sharing, crossfertilization of supervisory experiences, and synergizing of the shared responsibilities. The MoU is subject to modification or total revision whenever deemed necessary. 
fragile, due to a variety of factors including insufficient capital, limited institutional capacity, inordinate risk-taking, poor laws and regulations, and ineffective bank supervision. South African banks are gaining notable presence in the region and are establishing international operations.

South Africa generally dominates the financial markets in the SSA. Five of South Africa's banks, for example, ranked top in the region and are in the first 350 in world ranking. ${ }^{15}$ While Nigeria's best performer, Union Bank of Nigeria, ranks seventh in the region, its world ranking is 818. South Africa's level of intermediation, as measured by private sector credit to GDP, evidences the depth of its banking sector as compared with the other regional markets (Figure 1).

Figure 1. Selected Sub-Saharan African Countries: Ratio of Private Sector Credit to GDP

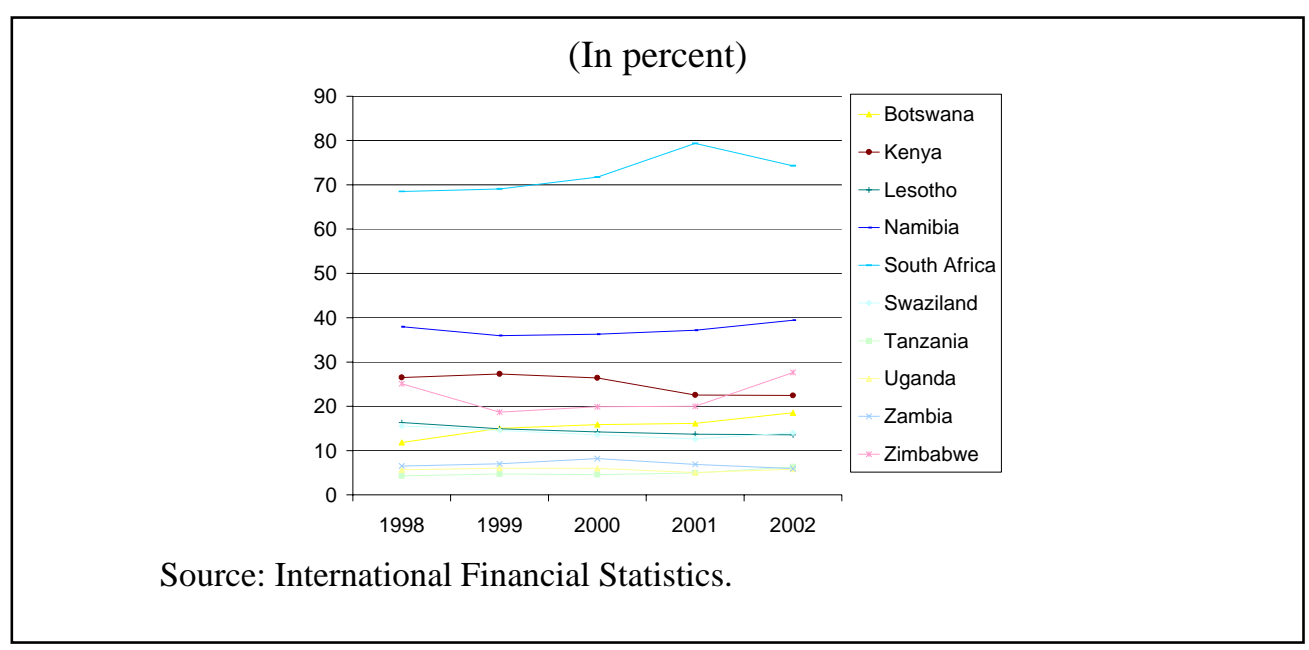

The role of the insurance sector is growing, as depicted by Figure 2 below. Zimbabwean banks have been increasing their presence in the region in the last decade, competing with South African banks for the regional cross-border market and country coverage. African Banking Corporation (a Zimbabwean bank) operates in Botswana, Mozambique, South Africa Tanzania, and Zambia.

With respect to the securities market, the Johannesburg Stock Exchange (JSE) is the largest exchange in Africa. Its market capitalization as of end-2002 stood at R676 billion.

${ }^{15}$ From the July 2004 The Banker: Standard Bank Group (116), ABSA Group (145), FirstRand Banking Group (218), Nedcor (252) and Investec (334) and African Bank (779). 
Figure 2. South Africa: Ratio of Premium to Total Assets

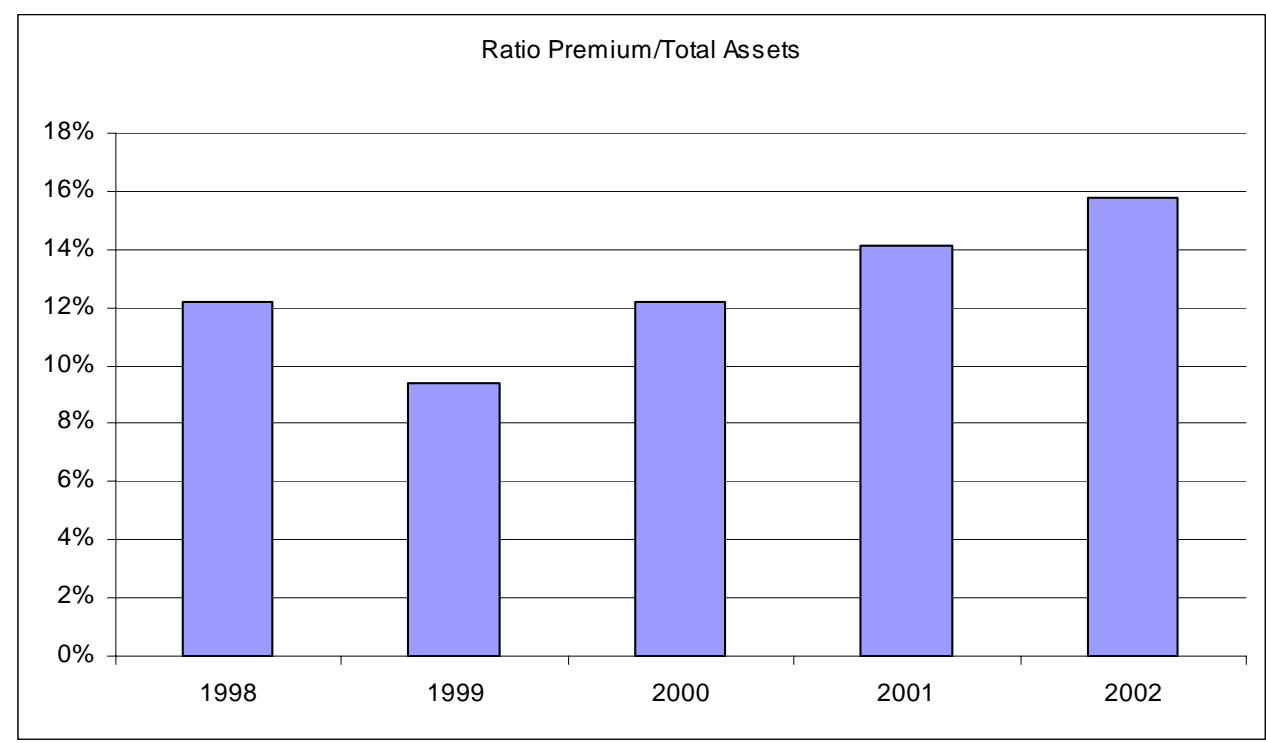

Source: Insurance Information and Statistics (ISIS) by Bureau van Dijk.

\section{A. Standard Bank Group}

The opening up of the South African financial sector in the early 1990s and post political regime change have resulted in a number of South African banks establishing operations within the eastern and southern Africa regions and globally. While a number of South African banks are gaining presence across borders, the Standard Bank Group (SBG) has the most notable and significant presence of the any of the country's banking groups. As shown in Table 4, the SBG's operations are in nine of the countries covered by the survey on the region compared to three countries where its major competitor in international outreach, FirstRand Bank Group, has a presence.

Although the SBG's operations, as measured by its share of the asset and deposit markets in the countries of operation, are significantly low in some countries, they are gaining prominence in a number of countries, for example, in Lesotho, Namibia, Swaziland, and Uganda. The group is evidently of systemic importance in the region and has an imminent cross-border financial impact in at least five of the countries surveyed.

The Standard Bank ${ }^{16}$ was established as the Standard Bank of British South Africa Limited and incorporated in London in 1862. Its evolution has resulted in developments that have led to its recent operational expansion beyond the southern African region into broader Africa and globally. In 1962, the Standard Bank of South Africa (SBSA) was formed and registered

${ }^{16}$ Standard Bank Group website www.standard.co.za. 
as a South African company, operating as a subsidiary of Standard Bank in London (subsequently to become Standard Chartered Bank plc). The SBG was established in 1969 as the holding company of SBSA. In 1987, Standard Chartered sold its stake in SBG, transferring complete ownership of the holding company to South Africa.

Table 4. Selected Sub-Saharan African Countries: Market Shares of Standard Bank Group’s Operations

(In Percent)

\begin{tabular}{lccc}
\hline & Assets & Deposits & Capital \\
\hline Botswana & 10.00 & 10.00 & 11.00 \\
Kenya & 1.92 & 2.02 & 1.37 \\
Lesotho & 24.00 & 20.70 & 19.10 \\
Namibia & 30.00 & 28.40 & 20.20 \\
Swaziland & 44.00 & 43.00 & 23.00 \\
Tanzania & 8.00 & 7.00 & 7.00 \\
Uganda & 29.34 & 32.19 & 2.94 \\
Zambia & 12.00 & 8.00 & 11.00 \\
Zimbabwe & 2.65 & 4.47 & 1.99 \\
\hline
\end{tabular}

Sources: Respective countries’ central banks: December 2001-December 2002.

The re-establishment of Standard Bank's African links began in 1988, when a branch was set up in Swaziland. In 1992, the group opened a Botswana bank and acquired a major African operation: the long-established ANZ Grindlays network in Botswana, Kenya, Uganda, Zaïre (now Dem. Rep. of Congo), Zambia, and Zimbabwe, with minority holdings in Ghana and Nigeria. The group has also continued to expand internationally with representative offices and trading operations in a number of international centers, including Hong Kong, London, and New York.

In addition to its banking operations, the SBG has interests in the insurance sector through control of the Liberty Group, one of Africa's leading life offices and financial services groups. However, the Group's operations in the eastern and southern Africa regions are predominantly banking. 


\section{B. Supervision of Financial Sector in South Africa and Collaboration on Cross-Border Surveillance}

Prior to political changes that occurred in 1994 introducing a democratically elected government, South Africa had limited banking operations outside the country. Apart from the banking operations in Namibia-which had a colonial history relationship with South Africa-most of the expansions into the region commenced in the early 1990s. Also prior to 1994, the South African Banking Law-The Banks Act, 1990-had prohibited the establishment of foreign bank branches in South Africa. Following the 1994 political changes, the Law was to allow for the establishment of foreign branch operations.

Unlike the trends evidencing banking supervision developments in the EU and Nordic countries of the signing of MoUs in member-country response to the emergence of a crisis, there are no formal guidelines among the Eastern and Southern Africa Banking Supervision (ESAF) members. The only MoU in place provides a framework for the intent to work toward the development of regional supervisory guidelines (Box 4).

There are other levels of cooperation within the eastern and southern Africa regions, of which are economic, collaborative, and integration bodies such the Common Market for Eastern and Southern Africa (COMESA), the Southern African Development Community $(\mathrm{SADC})^{17}$ — groups established to promote regional economic integration through trade and investment. Discussions have been held around the topic of macroeconomic convergence in both groups. However, the diversity of macroeconomic developments among member countries has been of notable influence on the progress made in the development of MoUs. Other regional groups include a banking supervision group - the ESAF group. The group, formed in 1993, comprises 17 countries and has its secretariat based in South Africa, reporting to the SADC Committee of Governors. ${ }^{18}$ The South African Reserve Bank (SARB) is responsible, as home country supervisor, for the supervision on a consolidated basis, of local and foreign establishments. Minimum capital adequacy requirement for a banking group is set at 10 percent of risk exposures, calculated on a risk-based aggregation method suggested by the Joint Forum on Financial Conglomerates.

Consolidated supervision covers the bank's controlling companies and their subsidiaries, joint ventures, and companies in which the bank has controlling interests. The controlling company in the group is required to prepare consolidated annual financial statements for review by the supervisor, but there are no risk management guidelines in place. In practice,

\footnotetext{
${ }^{17}$ Common membership of COMESA (20 members) and SADC (14 members) include Angola, the Democratic Republic of Congo, Malawi, Mauritius, Namibia, Seychelles, Swaziland, Zambia, and Zimbabwe.

${ }^{18}$ Other members of SADC, in addition to the list in footnote 17, are Botswana, Lesotho, Mozambique, South Africa, and Tanzania.
} 
the SARB limits schedule of on-site visits of the group's foreign operations to those considered materially important. Currently, none of the operations within the region are considered of material importance. Visits are paid as part of the normal course of duty of SARB staff visiting a country where the group has operations. Collaboration with the host regional supervisors appears minimal, if at all. Zimbabwe, which has had its banks expand into the region in the past decade or two, does not have systems in place for cross-border supervision.

\section{Box 4. Supervisory Collaboration and Cooperation in Eastern and Southern Africa}

As part of the integration into the regional financial markets, South Africa has been very active in working toward the development of regional supervisory systems. In 1993, together with 11 other countries in eastern and southern Africa, a regional banking supervision group, the Eastern and Southern Africa (ESAF) Banking Supervisors' group, was formed to work toward developing supervisory systems in the member countries. As of end-2002, ESAF had 17 member countries whose collaboration on the development of a harmonized system of regulation and supervision is guided by a memorandum of understanding and intent (MOUI). The main features of the MOUI include:

(i) Promotion and enhancement of the quality, nature, and ambit of banking supervision conducted by the members of ESAF.

(ii) Harmonization of banking supervision philosophies and practices among the members of ESAF.

(iii) International cooperation toward the development and maintenance of ordered and sound banking institutions within the ESAF region.

(iv) The implementation and maintenance of internationally acceptable standards of banking supervision within the respective supervisory jurisdictions of the members.

(v) Subscription and adherence to the minimum standards, pronouncements, and directives pertaining to the supervision of banks issued by the Basel Committee.

(vi) Endeavoring, through effective supervision, to promote the soundness of banks within their respective supervisory jurisdictions.

(vii) Contribute toward a healthier and sounder banking system in which depositors may enjoy greater protection, within the ESAF region.

\section{REgional AND Foreign BANK OWNERSHIP IN LATIN AMERICA}

Financial integration, that is cross-border activities of financial institutions in Latin America, ${ }^{19}$ is rather limited but increasing in some countries such as Salvadoran banks' lending to its neighboring countries. Physical presence, however, is more important in some

${ }^{19}$ This chapter is mostly based on presentations at a seminar on financial safety nets and regional integration in Latin America and the Caribbean, held on September 9, 2003, at the Inter American Development Bank (IADB) in Washington, D.C. The presentations are posted on the IADBs' website: http://www.iadb.org. 
countries than others, for example, in Argentina, Brazil, and Uruguay. Banco de la Nación Argentina operates in Brazil, Chile, and Uruguay. The Banco de la Provincia de Buenos Aires is present in Brazil and Uruguay. Four banking institutions each have a share in four different financial entities in Uruguay. Brazilian banks have three branches in Uruguay and two in Argentina. Brazilian investors own two banks in Argentina, one of which has over 100 branches, the most significant share belonging to the Banco de Brazil and the Banco de Ita'u. There is no Chilean investment in neighboring countries, although a few years ago, there was some minor investment in Argentine regional banks. Those banks were liquidated and sold because of the country's difficult economic situation in recent years. Uruguay has two banks in Brazil and one locally owned in bank in Argentina. Only Uruguay has offshore banking apart from the offshore centers in Central America and the Caribbean.

Although the importance of these operations in each country has not been quantified, in general, they are not significant. However, the presence of Argentinean banks in Uruguay was significant and the presence of Peruvian banks (Credicorp) in Bolivia can be regarded as significant. The Equadorean banking group Pichincha also has cross-border presence in several countries in the Andean region, including a bank in Peru that, while it is relatively small for the Peruvian market, its size is very large for the Equadorean banking system. There are limited cross-country interests in the banking system in Bolivia, Colombia, Equador, Peru, and Venezuela from other Latin American countries.

Foreign banks’ presence in Latin America is very important and has increased substantially in the last decade (Figure 3).

Figure 3. Foreign Control in Latin American Banking System 1/ (In percent of banking system in total of assets)

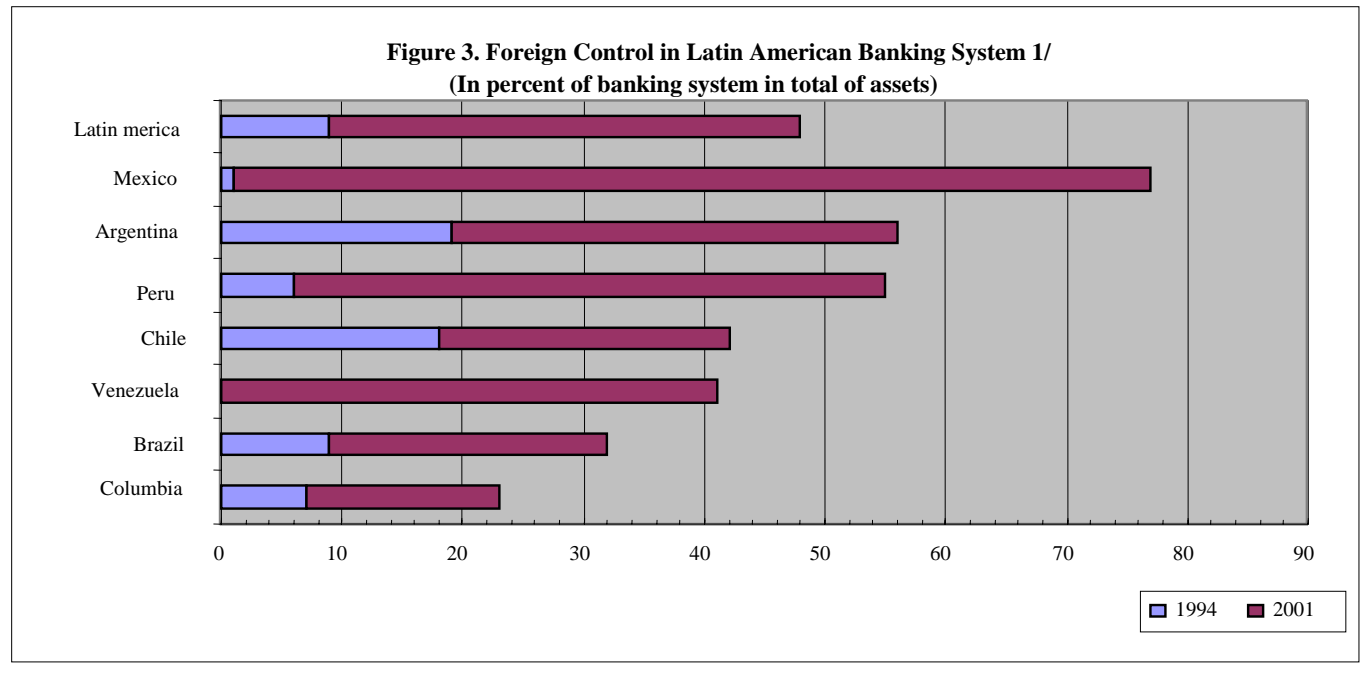

Source: 1/ José Luis Machinea and Verónica Rappoport. Financial safety nets and regional integration. seminar on integration and financial safety nets in Latin America and the Caribbean held at the IADB in Washington D.C., September 9, 2003. 
The presence of foreign banks in Latin America is not unique to the region. Large international banks have expanded their operations to the emerging economies of Asia and Central Europe with a view to increase their presence in those markets. However, a characteristic that distinguishes the presence of foreign banks in Latin America is that, apart from Citibank and more recently Spain's Banco Santander, the foreign banks present are not among the world's biggest. Other banks with representation in four or more Latin American countries are Banco Bilbao Vizcaya Argentaria (Spain), Bank of Nova Scotia (Canada), and Bank Boston (United States). Other foreign banks have presence in two or fewer countries. The first large-scale ventures by foreign banks in Latin America began in the 1980s and, except for specific cases (Citibank), the banks generally established representative offices or installed themselves by setting up local branches. These institutions focused on limited activities, mainly treasury operations and financing foreign trade operations. In the 1990s, however, foreign banks began to venture into more traditional conventional areas of the traditional banking system, such as consumer credit and mortgages to finance house buying. To enter the region's markets or increase their market share, foreign banks chose to buy local banks that were previously nationalized or in the hands of the private sector. Alternatively, if they were already established in the country, they chose to merge with local banks. In that way, they increased their market share and their capital base in the region.

When looking at the importance of foreign banks in Latin America, Mexico is the most salient case. In 2000, through the purchase of the most important banks in the market, foreign banks gained control through practically the entire financial system in Mexico. In Brazil, by contrast, Latin America's other great financial market, the presence of foreign banks has been less intense because of regulatory barriers and the strength of the local banking system.

Foreign banks clearly have a dominant position in Latin America, and the trend is for this position to be consolidated in the medium term. These circumstances pose challenges to the bodies that regulate and supervise the Latin American economies, obliging them to update regulations and bring them into line with international norms, so as to obviate possible regulatory disputes. It could be argued that the substantial presence of Spanish, U.S., and Canadian banks in the region would conspicuously hasten financial integration, if those countries were to choose to harmonize their regulations and stimulate the establishment of regional interbank markets. The more that the regulations governing banking systems are consistent and compatible with best practices, the more feasible is lasting regional integration in the financial sphere.

\section{A. Supervision of Financial Sector in Latin America}

Financial supervision in Latin America is typically vested with different sectoral agencies, one for banking (in some instances, banking and securities), another for securities, and the third for insurance. Supervision of banks is mostly conducted by governmental agencies and, in other instances, by the central banks. Unified financial supervision exists in Costa Rica, Honduras, Nicaragua, and Uruguay. However, the sectoral local supervisory authorities are increasingly cooperating and, in some instances, they have concluded formal agreements of collaboration or MoUs. 
The Latin American countries also have, in a number of instances, concluded MoUs with foreign supervisory authorities within the region, as well as outside the region on supervisory cooperation of cross-border activities. However, this type of agreement for effective crossborder cooperation of supervision of transnational banking has not been possible between all members of the region. For instance in the case of Bolivia, it appears that the banking supervisor does have limited authority for this type of exchange. However, Bolivia has signed an MoU with Peru which is the basis for Peruvian supervisory authorities to conduct a consolidated supervision of the Credicorp group. From the operational perspective, these agreements between regional supervisors have not proved to be of great importance, given the regulatory differences between member countries and, more basically, because of financial groups in the region do not tend to operate to a significant extent in other countries of the region as discussed earlier.

MoUs between supervisory authorities outside the region which have banking presence in Latin America and authorities within the region have been concluded in many cases. For example, Bank of Spain has signed MoUs with most Latin American supervisory agencies.

The recent financial crises in some countries in Latin America and the Caribbean have led to increased discussions on future financial supervisory arrangements, also in light of financial integration, and not least, increased foreign banks' market share in many countries in the region. This has been discussed in the forum of the regional supervisory groups, and the topic has also been taken up on the agenda of seminars and workshops arranged by the Inter American Development Bank in Washington, D.C. A few countries in the region have started to analyze the feasibility of integrated supervision, and others have already modified the legislation to further facilitate closer cooperation between sectoral supervisory agencies.

\section{CASE FOR Signing MEMORANDA OF UNDERSTANDING}

The guidelines issued by the Basel Committee on Banking Supervision have gone a long way in assisting cross-border cooperation among supervisors. First, the issuance of the concordat establishes understandings relating to contact and collaboration between home and host country authorities in the supervision of banks' cross-border establishments. This is further enhanced by the Basel Committee's issuance of The Supervision of Cross-Border Banking in 1996, which establishes a foundation for information sharing among supervisors and has contributed to the removal of obstacles to the implementation of effective consolidated supervision. Second, the encouragement by the BCBS for countries to form regional groups has provided a platform for information sharing at a regional level. While most of the groups operate on an informal basis, they seem to be recognized as pressure groups in policy formulation and guiding the supervisory developments at country and regional levels. Third, in countries where there is low political will and interference in the development of financial sector supervision policies and their implementation, group pressure has helped country supervisors to make a case for fostering prudent behavior. 
Against these perceived developments, however, there are a number of issues that require improvement. Many supervisors, including those in countries with developed financial systems, use moral suasion to offset the delays in the adoption of the Basel and other financial standard setting bodies' guidelines. While the formation of supervisory groups may help countries focus on issues that need to be addressed in the transition toward harmonization of supervisory practices and address country, regional and global systemic crises, very few supervisory groups may have enforceable agreements in place.

As exemplified by the ESAF Banking Supervisors Group, regional supervisory groups are at a nascent stage, with MoUs providing the framework for collaboration but not the details of the collaborative mechanisms and procedures. Following the lessons from the financial crises of the 1990s, the Nordic countries' work toward developing supervisory instruments (partly mirrored against the EU directives) is instructive. There may be a need for supervisory bodies to emulate the EU and Nordic countries' developments of entering into MoUs. The transfer of the risk-management responsibility to the management of financial organizations has met with impediments, occasioned by several factors, including: weaknesses in the supervisory framework, weak enforcement mechanisms (especially in developing countries) exacerbated by lack of depth in supervisory skills, political interference, corruption, and other problems.

How should countries go about developing their supervisory capacity to respond to financial crises, and how should the systems be coordinated to form a cohesive regional response to systemic crises?

A number of issues require consideration in working toward regional or cross-border cooperation in developing systems for responding to financial crises. First and foremost, there must be a common understanding among cooperating countries over the need to have response mechanisms to systemic financial crises. In systemic banking crises, major government intervention is required even in countries strongly committed to market-oriented policies (Lindgren, and others, 1999). Second, strategies for handling financial crises have sought to incorporate good practices from international experience, which underscores the importance of prompt and decisive action in working toward financial re-stabilization. Thus, the lesson is that once the mechanisms have been agreed upon and established, the collaboration environment should allow for enforcement and reviews of the agreed upon guidelines to develop effective mechanisms on an ongoing basis. The issues which require consideration include:

- $\quad$ The establishment of the systemic importance of a large and complex financial institution or financial conglomerate in the country of origin.

- $\quad$ The establishment of systemic importance of the subsidiary or branch in the host country. 
- If the entity is a cross-sector operation, the development of mechanisms for cooperation among various financial sector supervisors (banking, insurance, and securities).

- $\quad$ The establishment of mechanisms for liquidity support and instruments for sterilization.

- $\quad$ Availability of safety nets.

- The existence of provisions in the legislative framework for the closure of insolvent banks or institutions and the establishment of systems for the resolution of failing conglomerates.

\section{CONCLUSION}

Domestic financial markets are becoming increasingly integrated across sectors — that is, banking, insurance, and capital markets. This is also true for cross-border financial conglomerates. This trend has been evolving over a number of years, especially in the developed countries but increasingly in the emerging market countries and, to some extent, in the developing countries. The developments call for special supervisory attention with respect to country responses in dealing with country-specific systemic crises and, with the growing trend toward regional cross-border operations, group preparedness for dealing with a crisis.

Close cooperation between sectoral supervisory agencies, central banks, and ministries of finance is crucial in the event financial difficulties occur in a financial conglomerate and, as exemplified by the Nordic cooperation on Nordea, large bank specific MoUs should be considered, even in cases where the operations may be purely banking, as is true of the fast-growing Standard Bank Group. It is not enough to sign a MoU, since to be effective operationally, it has to be put into practice and preferably be tested using different scenarios. Generally, MoUs are signed when there are no or few problems facing the authorities, and, consequently, when they are challenged, they can be easily put to test.

The cooperation within Nordic countries between the supervisory authorities, central banks, and respective ministries could be used as a model for other regions, even on a smaller scale. However, unless the respective countries in a region are committed to cooperation and harmonization in the supervision and development of the regional financial sectors and/or have a common history and tradition are characterized by macroeconomic stability and have highly developed financial systems, the goal of establishing mechanisms to address systemic crises may prove to be excessively complex and an extended challenge. However, owing to the increasingly complex structures of large cross-sector and cross-border financial conglomerates or large banks, this cooperation must be strengthened on a regional and, to some extent, global basis. The cooperation between the supervisory authorities in Eastern and Southern Africa is a good example of cooperation that can serve the region well, but needs to be supported by the development of enforceable, action-oriented MoUs. The question of how 
reliable MoUs are remains, since they have not been tested. During the BCCI debacle, supervisors acted unilaterally to save their specific countries’ situations.

Financial crises occur despite the presence of elaborate bank or financial regulatory and supervisory structures. It could be concluded that the existing structure may not be appropriate for fulfilling its assigned responsibilities. However, one of the main challenges is casting the regulatory and supervisory net over all institutions legally defined as banks or financial conglomerates. A broad perspective suggests that extensive and system-wide financial regulation, and supervisory collaboration and cooperation need to be complemented by market discipline. Agreements among supervisors depend, to a considerable extent, on the conduct of the market players, over whom the large players have significant influence. A complementary system of market discipline and MoU arrangements among supervisors may provide additional comfort to efforts to strengthen frameworks for banking supervision devised by the BCBS.

For many countries, efforts required to bring their domestic banking systems up to contemporary standards are complex and costly, and shouldering supervisory responsibilities extending beyond domestic concerns - especially those involving large complex financial institutions - poses even greater challenges for many countries, whether they are host or home supervisors. The joint IMF-World Bank FSAP recognizes the need for international financial institutions to assist countries in broadly assessing vulnerabilities in their financial systems. As this work has progressed, the assessments made have indicated the need to give special attention to the role played by LCFIs. Although the IMF and the World Bank recognize that the primary responsibility for addressing vulnerabilities posed by significant cross-border banking operations lies with the countries themselves, it is clear that FSAPs should be extended to cover the challenging development of LCFIs and cross-border financial conglomerates in an increasingly integrated financial system, regionally and globally. 


\section{MEMORANDUM OF Understanding AMONg NoRdic CENTRAL BANKS}

\section{Management of a financial crisis in banks with cross-border establishments}

Memorandum of Understanding (MoU) between the central banks of Denmark, Finland, Iceland, Norway and Sweden

Introduction:

The central banks of Denmark, Finland, Iceland, Norway and Sweden all have responsibility for national financial stability and a role as providers of emergency liquidity assistance where necessary. The increasing prevalence of cross-border banks and bank establishments entail risks of a financial crisis in a Nordic banking group having repercussions for financial stability in more than one of these countries. For this reason, the central banks of Denmark, Finland, Iceland, Norway, and Sweden have drawn up this MoU with a view to facilitating the management of such a situation.

The MoU is based on the following principles:

- The cooperation between the central banks will be facilitated by the establishment of a structure for crisis management and dissemination of relevant information. In the event of a financial crisis, it is important that the cooperation between the affected central banks works quickly and efficiently.

- A nonlegally binding MoU is an appropriate instrument for facilitating cooperation between the central banks without curtailing their flexibility as independent institutions.

The MoU between the Nordic central banks is based on and makes more concrete the MoU that has been concluded by the central banks and supervisory authorities within the European System of Central Banks (ESCB) in respect of both crisis management and payment systems. The MoU does not affect or bypass the powers of the national authorities or their international undertakings or agreements on cooperation.

The MoU constitutes a general framework. Where deemed appropriate, the Nordic central benks may enter into separate MoUs in respect of more detailed arrangements for cooperation and information exchange for the management of crises in individual, specified banking groups.

\section{The parties to this MoU are in agreement on the following:}

\section{Scope of cross-border cooperation in crisis management situations}

1.1 The MoU may be applied in the event of a financial crisis in a Nordic bank with operations in two or more Nordic countries. 


\section{Conditions regarding solvency and liquidity}

2.1 The responsibility for managing a financial crisis in a bank rests primarily with its owners and management. It is expected that problems in parts of a banking group will be solved by making use of the collective financial strengths of the whole banking group. Thus, emergency liquidity assistance from the central banks will only be provided in exceptional circumstances.

2.2 A bank can encounter diferent kinds of liquidity problems. Usually, the problems affect the entire banking group or groups of companies. In exceptional cases, liquidity problems may be local in nature, e.g., due to technical disruptions in the payment systems. However, in general, if the parent bank cannot obtain funding in the market or through the central bank's customary sources of liquidity, such as monetary policy credits or intraday credits, neither will the subsidiary banks have this option. Conversely, as long as the parent bank is capable of obtaining funding in the market, it can always fund its subsidiary banks.

2.3 Where liquidity problem affects the banking group as a whole, the provision of emergency liquidity assistance will inevitably benefit the entire group. Consequently, a decision by one or more central banks to provide or not to provide emergency liquidity assistance to a cross-border Nordic bank will have implications for the other Nordic central banks as well.

2.4 In all the Nordic central banks, one of the conditions for a decision to provide emergency liquidity assistance is that the bank in question is not judged to be insolvent. In cases where a bank is judged to be insolvent or where its solvency is deemed uncertain, the central banks are required to contact their respective MoF immediately.

2.5 A solvency problem in a banking group may affect individual institutions within the group and does not therefore have to affect all group institutions or the group as a whole. The parent bank or the group could be insolvent and therefore be forced to sell its solvent subsidiary bank to be able to pay its debts. A subsidiary bank could be insolvent and require financial assistance from its parent bank to be able to pay its debts.

\section{Crisis management group}

3.1 In the event of a crisis, it is necessary that the central banks have a crisis organization that enables the efficient acquisition and analysis of information to allow a quick assessment of the need for policy measures and make appropriate proposals. In order to ensure this, a contact group will be established, consisting of one high level representative from each of the concerned central banks and an alternate who shall take the place of the ordinary representative in his/her absence. 
3.2 In the event of a crisis, the contact group shall become a crisis management group. All representatives, in their work in the crisis organization, shall be able to communicate directly with their respective central bank's executive board.

3.3 The principal aim of the crisis management group is to provide all central banks with quick access to the same information and to enable the direct discussion and coordination of potential measures.

3.4 The central bank that is first to identify a potential crisis shall activate the crisis management group. The central bank of the country where the management of the banking group is domiciled, in practice, shall thereafter be responsible for coordinating the crisis management group's continued work.

3.5 Where appropriate and time permitting, each central bank may allow its representative, or the representative's alternative, to attend the crisis management group meeting in person.

3.6 Any member of the crisis management group may request that the crisis management group' discussion be held in English and that the background material for decisions of the executive boards of the central banks (described in more detail in point 4.1 below) be drawn up in this language.

\section{Tasks of the crisis management group}

4.1 The crisis management group will be responsible for producing background material to facilitate potential decisions of the central banks' executive boards with regard to emergency liquidity assistance or other rlevant measures. This bacground material should, in addition to presenting information on systemic importance and solvency, clarify any differences of opinion between the affected central banks. Decisions by the respective central bank shall be taken in accordance with its normal decision-making procedures.

4.2 The first task of the crisis management group will be to ascertain the bank's liquidity and solvency situation and other relevant factors through direct communication with the management of the banking group.

4.3 The crisis management should contact the supervisory authorities responsible for the banking group in the Nordic countries as soon as possible with a view to exchanging information., and should also request a solvency assessment for the banking group and its different banks.

4.4 The crisis management group may also contact other persons, within or outside the central banks, to obtain information or analyze the situation at hand. 
4.5 The crisis management group shall, when so requested, produce background material for the central banks' and other authorities' contacts with international bodies, such as the European Commission and the ECB, which by agreement or some other means have the right to be informed/consulted.

\section{Information management}

5.1 Internal information between the central banks and external information to the media should, as regards its content, be coordinated through the crisis management group as far as possible.

5.2 Communication with the relevant bank's supervisory group, where such a group has been established, shall be handled by the crisis management group. The individual central banks, however, shall handle communication with the respective country's supervisory authority and MoF.

5.3 Once the crisis management group has been activated, communication with the banking group should primarily be conducted between the crisis management group and the management of the banking group. The management of the banking group is expected to inform its own banks irrespective of their country of location.

5.4 In cases where the Nordic central banks draw up a separate MoU in respect of a specified financial group, one of the central banks shall be made responsible for ensuring that a fact book containing relevant public information about the group is updated regularly. The purpose of the fact book is to give the central banks a common body of knowledge about the structure of the group's business activities and balance sheet. 


\section{NORDEA GROUP}

\section{Nordbanken}

Nordbanken's origins stem from PKbanken founded in 1974 through the merger of Sveriges Kreditbank and Postbanken. The name Nordbanken was first established when Sundsvallsbanken and Uplandsbanken merged in 1986. In 1990 PKbanken bought Nordbanken and took on the name.

\section{Merita}

Merita Bank was created in 1995 when Kansallis-Osake-Pankki merged with Unitas Ltd, the holding company of Union Bank of Finland, and the banking activities of the two banks were merged.

\section{KOP}

In 1889, Kansallis-Osake-Pankki was established. In 1992, it merged with Suomen Työväen Säästöpankki (savings bank of the Finnish labor movement) and in 1993, KOP and Union Bank of Finland acquired and divided with two other banking groups, the business of Suomen Säästöpankki (Savings Bank of Finland), formed only two years previously.

\section{SSP}

In 1991, Suomen Säästöpankki (Savings Bank of Finland) was established. In 1993, KOP and Union Bank of Finland acquired and divided with two other banking groups the business of SSP.

\section{STS}

Suomen Työväen Säästöpankki (savings bank of the Finnish labor movement) was established 1905, but its origins date back to 1822. During the years, it converted from a savings bank to a commercial bank and ceased to operate as an independent bank in 1992, following its merger with Kansallis-Osake-Pankki.

\section{Unitas/UBF}

In 1862, Finland's first commercial bank, Suomen Yhdyspankki, was established. Following a major merger in 1919, Suomen Yhdyspankki was known as Pohjoismaiden Yhdyspankki until 1975, when it adopted the English name of Union Bank of Finland, which was used internationally. As early as the 1970s, the bank became a pioneer in the development of electronic banking services. 


\section{Pkbanken}

PKbanken was formed in 1974 by the government as an alternative to the large private banks. It was also a way to avoid restructuring Postbanken, the postal services bank, into an independent commercial bank. In 1984, the state's ownership decreased to 84.4 percent as new shares were issued. In 1989, PKbanken bought Investeringsbanken to enable expansion within the investment field, and the following year in 1990, PKbanken bought Nordbanken and took on the same name.

\section{Gota Bank}

In 1993 Nordbanken acquired Gota Bank, which in turn had been formed in 1990 through the merger of Wermlandsbanken, Skaraborgsbanken, and Götabanken. The latter was established in 1972 through a merger of Göteborgs Bank and Smålandsbanken. The three banks continued to operate under their own names since it was deemed important to maintain a regional connection.

\section{Andelsbanken}

Established in 1925. In 1990, Unibank was formed through the merger of Privatbanken, SDS Bank, and Andelsbanken. Before the merger, the bank had strong ties to Denmark's large agricultural cooperatives. It evolved from being a farmers' bank to embracing billion kroner businesses with the manufacturing industry as well.

\section{SDS Bank}

The largest Danish savings bank at the time. Its origins date back to 1820, when the first Danish town savings bank was established. SDS Bank was established in 1973 through the merger of three major regional savings banks. In 1990, Unibank was formed through the merger of Privatbanken, SDS Bank, and Andelsbanken. Before the merger, SDS Bank had the largest number of personal customers in Denmark, making it very strong in terms of retail banking.

\section{Privatbanken}

Privatbanken was Denmark's largest bank at the time [1992]. It was founded in 1857 by the legendary tycoon C F Tietgen, who became managing director. In 1990, Unibank was formed through the merger of Privatbanken, SDS Bank, and Andelsbanken. At the time of the merger, Privatbanken had particular strengths in lending to larger corporations, securities trading, and international activities.

\section{Unidanmark/Unibank}

In 1990, Unibank was formed through the merger of Privatbanken, SDS Bank, and Andelsbanken. Following the merger, Unibank had some difficult years, culminating in the 
severe 1992 crisis which hit the entire financial services sector in Denmark. In March 1999, Unidanmark, the parent company of Unibank, and Tryg-Baltica, Denmark's largest insurance company, agreed to merge their operations to form a leading Nordic financial services group.

\section{Tryg-Baltica}

The Tryg-Baltica Group was formed in 1995 as a result of a merger of two Danish insurance companies, Tryg Forsikring and Baltica Forsikring. In 1999, Tryg-Baltica merged with Unibank, and the following year both companies became part of the Nordic merger to form Nordea. In November 2001, the insurance company changed its name to Tryg Forsikring. In the summer of 2002, the general insurance activities were sold to Tryg smba.

\section{Vesta}

The Norwegian insurance company Vesta was founded in 1880. Tryg Forsikring acquired Vesta in 1999, and today the company forms part of Nordea Life Holding A/S Denmark.

\section{MeritaNordbanken}

On November 26, 1997, at a general meeting of Merita Abp, the shareholders accepted the public offer from Nordbanken Holding, and the companies merged. MeritaNordbanken became one of the leading banking groups in the Baltic region, with strong positions in two home markets. At the time of the merger, the customer base comprised approximately 6.5 million private individuals and nearly 300,000 companies.

\section{Christiania Bank og Kreditkasse}

The bank was established in 1848. As of 1851, the official name of the bank was changed to Christiania Bank og Kreditkasse. In September 1999, MeritaNordbanken made an offer for all the shares in Christiania Bank og Kreditkasse. On December 28, 2000 Christiania Bank og Kreditkasse became a part of Nordea, the Nordic financial services group.

\section{Postgirot Bank}

Postgirot was founded in 1925 as an activity of the Postsparbanken (Postal Savings Bank) of that time. Postgirot Bank AB (publ) became a wholly owned subsidiary of Nordea on December 3, 2001.

\section{Nordic Baltic Holding}

The holding company, Nordic Baltic Holding, was established in the beginning of 2000 by the unification of Merita Abp and Nordbanken Holding owner companies. (See following chart). In October of the same year, the name of the new Nordic group was changed to be Nordea ('Nordic Ideas'). 
The Nordic Baltic Holding consisted of a parent company and two main subsidiaries, one banking group parent and one insurance group parent as follows:

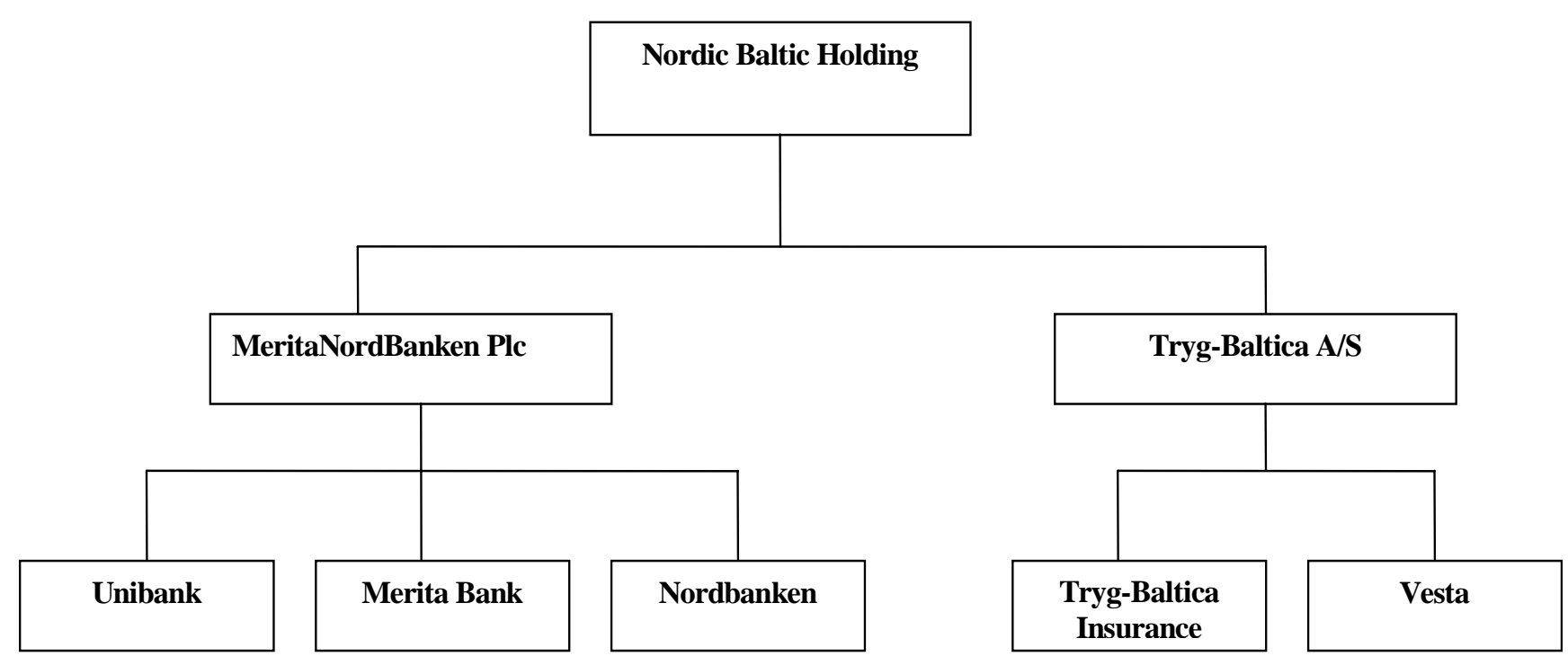

2001

In December 2001, each bank belonging to the Nordea group changed its name to Nordea Bank (Denmark, Finland, Norway, or Sweden, respectively). The following major events in the legal structure of the Nordea has taken place after the creation of the new Nordic group, Nordea:

2002

Nordea Bank Sweden and Postgirot Bank AB merged. Nordea Bank Sweden bought the Polish bank LG Petro which is one of the 15 largest financial institutions in Poland. Nordea sold all its insurance activities (except life insurance) to Tryg i Denmark.

2003

In June 2003, the Board of Directors of Nordea AB announced its decision to change the Nordea Group's legal structure. The goal was to create one European company- “Societas Europeae," (SE) based on the European Company Statue which came into force in late 2004. The aim was to establish a one-bank structure, with one legal entity conducting business in all local markets through branches. Nordea AB will become an operational banking company and will be converted into a European company continuing to be legally domiciled in Sweden. The change process will start by internal sales of Nordea Bank Denmark, Nordea Bank Norway, and Nordea Bank Sweden from Nordea Bank Finland to Nordea AB (the parent company) and by subsequent mergers of Nordea AB and Nordea Bank Sweden. When 
it is legally possible to create the European company, the other banks in the group are to be merged into this company. The change in process is expected to be finalized in 2005.

\section{4}

On January 30, 2004 the parent company, Nordea AB (publ), was granted a bank charter and changed its name to Nordea Bank AB (publ). The next step is that Nordea Bank Sweden will be merged into Nordea Bank AB which is part of a process aimed at creating a European company. The merger is scheduled to take place on March 1, 2004. 


\section{REFERENCES}

Bank for International Settlements, Basel Committee on Banking Supervision, 2003, "Management and Supervision of Cross-Border Electronic Banking Activities," July (Basel).

The Banker, July 2002.

Basel Committee on Banking Supervision, 1983, "Principles for the Supervision of Banks' Foreign Establishments,” May (Basel).

— 1992, "Minimum Standards for the Supervision of International Banking Groups and their Cross-Border Establishments,” July (Basel).

—

_ 2001, "Essential Elements of a Statement of Cooperation Between Banking Supervisors,” May (Basel).

Hartmann, Philip, Angela Maddaloni, and Simone Manganelli, 2003, The Euro Area Financial System: Structure Integration and Policy Initiatives, European Central Bank, Working Paper Series No. 230, May.

Ingves, Stefan M., “ The Nordic Banking Crises from an International Perspective,” Speech delivered at Seminar on Financial Crises-Ten Years After the Nordic Banking Crises, held in Oslo, Norway September 2002. Published on the Banking, Insurance and Securities Commission of Norway website: www.kredittilsynet.no

International Monetary Fund (IMF), 2001, Finland FSSA Report, Country Report No. 01/214, 11/2001 (Washington).

—_, 2002, Sweden FSSA Report, Country Report No. 02/161, 07/2002, (Washington).

—_, 2003, Global Financial Stability Report, May 2003 (Washington).

Johnston, R. Barry, Baláz Horváth, Luca Errico, and Jingquing Chai, 2002, Large and Complex Financial Conglomerates: Domestic and Cross Border Challenges and Policy Responses, IMF Policy Discussion Paper, 03/01 (Washington: International Monetary Fund).

Koskinkylä, Heikki, “ The Nordic Banking Crises,” Bank of Finland, Bulletin No. 8/1995. Kredittilsynet, 1999, "Rapport om Problemstillinger vedrörende konsesjonbehandling og tilsyn med banker og forsikringsselskaper under ulike former for konsolidering over landegrensene,” December (Oslo). 
Lindgren, Carl-Johan, Tomás J.T. Baliño, Charles Enoch, Anne-Marie Gulde, Marc Quintyn, and Leslie Teo, 1999, Financial Sector Crisis and Restructuring Lessons from Asia, IMF Occasional Paper No. 188 (Washington: International Monetary Fund).

Management of a Financial Crisis in Banks with Cross-Border EstablishmentsMemorandum of Understanding (MoU) between the Central Banks of Denmark, Finland, Iceland, Norway, and Sweden: June 2003.

Memorandum of Understanding between Kredittilsynet (The Banking, Insurance and Securities Commission of Norway), Finansinspektionen in Sweden, The Financial Supervision Authority in Finland, The Insurance Supervision Authority in Finland, The Financial Supervisory Authority in Iceland, and the Financial Supervisory Authority in Denmark regarding cooperation on supervision of credit institutions following the implementation of the Second Banking Coordination Directive, supervision of insurance undertakings following the implementation of the Third Non-Life Insurance Directive and the Third Life Assurance Directive, and supervision of investment firms following the implementation of the Investment Services Directive: May 2000.

Memorandum of Understanding between Kredittilsynet (The Banking, Insurance and Securities Commission of Norway) Finansinspektionen in Sweden, The Financial Supervision Authority in Finland, The Insurance Supervision Authority in Finland and The Financial Supervisory Authority in Denmark regarding the cooperation in the supervision of the Nordic Baltic Holding Group: October 2000 and revised in May 2001.

Memorandum of Understanding on High-Level Principles of Cooperation between the Banking Supervisors and Central Banks of the European Union in Crisis Management Situations: March 2003.

Miles, Colin, 2002, “Large and Complex Financial Institutions: Issues to be Considered in Financial Sector Assessment Program,” Operational Paper No. 02/3, March (Washington: International Monetary Fund).

Nordea Annual Reports 2000, 2001 and 2002 (Stockholm).

Nordea, Annual Review, 2002 (Stockholm).

Nordea's website www.nordea.com.

Steven A., Seelig, and Peter J. Elmer, “Risks Associated with Mega Financial Institutions” in "Megamergers in a Global Economy, Causes and Consequences, edited by Benton E. Gup, published by Quorum Books in Westport, Connecticut and London in 2002.

South African Reserve Bank website www.reservebank.co.za. 
Standard Bank Group website at www.standard.co.za.

Transparency International's Corruption Perception Index, available on the Web at http://wwwuser.gwdg.de/ uwvw/corruption.cpi 2003 data.html. 